\title{
Evidence of reaction intermediates in microwave-assisted synthesis of SHG active $\alpha-\mathrm{La}\left(\mathrm{IO}_{3}\right)_{3}$ nanocrystals
}

\author{
Sylvain Regny, ${ }^{a}$ Yan Suffren, ${ }^{b}$ Olivier Leynaud, ${ }^{a}$ Isabelle Gautier Luneau, ${ }^{a} *$ Géraldine Dantelle ${ }^{a} *$
}

We explore here how, under microwave assisted hydrothermal process, various synthesis conditions influence the formation of different lanthanum iodate compounds: $\alpha-\mathrm{La}\left(\mathrm{IO}_{3}\right)_{3}, \mathrm{La}\left(\mathrm{IO}_{3}\right)_{3}\left(\mathrm{H}_{2} \mathrm{O}\right), \mathrm{La}\left(\mathrm{IO}_{3}\right)_{3}\left(\mathrm{HIO}_{3}\right)$ and $\mathrm{La}\left(\mathrm{IO}_{3}\right)_{2.66}(\mathrm{OH})_{0.66}$. Whatever the intial $\left[\mathrm{La}^{3+}\right]:\left[\mathrm{IO}_{3}{ }^{3}\right]$ ratio, $\alpha$ - $\mathrm{La}\left(\mathrm{IO}_{3}\right)_{3} \mathrm{crystallizes}$ if the synthesis temperature exceeds $220^{\circ} \mathrm{C}$. Phase transformations in solid state or under hydrothermal synthesis are also discussed. Interestingly, we evidence the full phase transformation under hydrothermal synthesis from the new hydrate form $\mathrm{La}_{(}\left(\mathrm{IO}_{3}\right)_{3}\left(\mathrm{H}_{2} \mathrm{O}\right)$ into stable and optically active $\alpha$-La(IO $)_{3}$ through an appropriate hydrothermal process. This evolution can be explained by structural rearrangements of the coordination sphere of lanthanum atoms, stabilizing the structure.

\section{Introduction}

The search for new frequency converters in the mid-infrared region has attracted great interest for several decades, with the goal of expanding commercial laser wavelengths into atmospheric transparency windows II $(3-5 \mu \mathrm{m})$ and III (8- 12 $\mu \mathrm{m})$. Today, it is still very challenging to design new mid-IR transparent non-centrosymmetric crystals with large nonlinear optical (NLO) coefficients for applications as bulk single-crystals for laser technology, ${ }^{1}$ as waveguides for confined photonic devices ${ }^{2}$ and also as nanostructured materials for bio-imaging., ${ }^{3,4}$ Different families of materials have been studied considering their crystalline structure, with the goal of obtaining large NLO effects (metal chalcogenides, selenites, ${ }^{6}$ tellurites, ${ }^{7}$ iodates ${ }^{8,9,10}$ ).

In metal iodates, according to the 3D arrangement of these $\mathrm{IO}_{3}$ polyhedra and the lone electron pair of $\mathrm{I}^{5+}$, strong macroscopic susceptibility can be obtained, giving rise to highly efficient NLO properties. ${ }^{11}$ A complete review on metal iodates has been recently published by C.L. Hu and J.G. Mao, ${ }^{12}$ featuring the different compounds and discussing their SHG efficiency. Briefly, metal iodates encompass different materials, from first studied $\mathrm{LilO}_{3}$ to divalent metal iodates $\mathrm{M}\left(\mathrm{IO}_{3}\right)_{2}(\mathrm{M}=\mathrm{Mg}, \mathrm{Mn}$, $\mathrm{Co}$, etc. $)^{13}$, trivalent metal iodates $\mathrm{M}\left(\mathrm{IO}_{3}\right)_{3}(\mathrm{M}=\mathrm{Fe}, \mathrm{Ga}$, La, etc.), ${ }^{10,14}$ bimetallic compounds such as $\mathrm{AgM}\left(\mathrm{IO}_{3}\right)_{4}{ }^{15,16}$ $\mathrm{BaVO}\left(\mathrm{IO}_{3}\right)_{5},{ }^{17}$ and other compounds such as $\mathrm{BiO}\left(\mathrm{IO}_{3}\right) .{ }^{11}$ Most of these compounds can be obtained by dissolution/recrystallization or under mild hydrothermal conditions $\left(\mathrm{T}<300^{\circ} \mathrm{C}\right)$. A difficulty in the synthesis of these

\footnotetext{
${ }^{a}$ Univ. Grenoble Alpes, CNRS, Grenoble INP, Institut Néel, 38000 Grenoble, France. ${ }^{b .}$ Univ Rennes, INSA Rennes, CNRS UMR 6226 "Institut des Sciences Chimiques de Rennes", F 35708 Rennes, France.
}

compounds is polymorphism. Indeed, polymorphic forms exist for many iodate compounds: $\mathrm{LilO}_{3},{ }^{18} \ln \left(\mathrm{IO}_{3}\right)_{3},{ }^{10} \mathrm{Cd}\left(\mathrm{IO}_{3}\right)_{2},{ }^{19}$ etc. As some of them are centrosymmetric and the others non-centrosymmetric, it is essential to get a rigorous control of the synthesis parameters to form the appropriate crystal for the targeted applications. Furthermore, the coordination number of a metal cation is all the more variable as the ionic radius is large, favoring the polymorphism of a compound or the coordination of other ligands such as solvates. ${ }^{20,21}$ This is particularly the case for lanthanum iodates: according to the synthesis conditions (temperature, $\mathrm{pH}$, concentration, $\left[\mathrm{La}^{3+}\right]:\left[\mathrm{IO}_{3}{ }^{-}\right]$molar ratio), crystallization from aqueous solutions of lanthanum salts leads to a lot of different lanthanum iodate phases. Many hydrate lanthanum iodate phases have been described in the literature: $\mathrm{La}\left(\mathrm{IO}_{3}\right)_{3} \cdot 0.5 \mathrm{H}_{2} \mathrm{O},{ }^{22} \mathrm{La}\left(\mathrm{IO}_{3}\right)_{3} \cdot 6 \mathrm{H}_{2} \mathrm{O},{ }^{23}$ $3 \mathrm{La}\left(\mathrm{IO}_{3}\right)_{3} \cdot \mathrm{HIO}_{3} \cdot 7 \mathrm{H}_{2} \mathrm{O}{ }^{24} \quad 2 \mathrm{La}\left(\mathrm{IO}_{3}\right)_{3} \cdot 3 \mathrm{HIO}_{3} \cdot 6 \mathrm{H}_{2} \mathrm{O}$, $3 \mathrm{La}\left(\mathrm{IO}_{3}\right)_{3} \cdot 2 \mathrm{HIO}_{3} \cdot 6 \mathrm{H}_{2} \mathrm{O}$ and $2 \mathrm{La}\left(\mathrm{IO}_{3}\right)_{3} \cdot 3 \mathrm{H}_{2} \mathrm{O},{ }^{25}$ along with a hydroxyl phase, $\mathrm{La}_{3}\left(\mathrm{IO}_{3}\right)_{8}(\mathrm{OH}),{ }^{26}$ and anhydrous $\mathrm{HIO}_{3}$-containing lanthanum iodates: $\mathrm{La}\left(\mathrm{IO}_{3}\right)_{3}\left(\mathrm{HIO}_{3}\right)$ and $\mathrm{La}\left(\mathrm{IO}_{3}\right)_{3}\left(\mathrm{HIO}_{3}\right)_{1.33} .^{27}$ Upon annealing of these latter phases, anhydrous lanthanum iodates are obtained, namely $\beta-, \gamma^{-}$, $\delta$ - $\mathrm{La}\left(\mathrm{IO}_{3}\right)_{3}{ }^{27}$ As for $\alpha-\mathrm{La}\left(\mathrm{IO}_{3}\right)_{3}$, first anhydrous lanthanum iodate to have been synthesized, ${ }^{15}$ it is obtained through hydrothermal route, with no evidence of phase transformation between the known lanthanum iodates and $\alpha$ - $\mathrm{La}\left(\mathrm{IO}_{3}\right)_{3} \cdot{ }^{27}$ It suggests a high stability of the $\alpha$ phase, yet it is the most efficient for SHG with a NLO response evaluated as ca. 400 times that of well-known $\mathrm{SiO}_{2}$ quartz. ${ }^{15}$ Very recently, F.-F. Mao et al. reported the synthesis of two new compounds, $\mathrm{La}_{3}\left(\mathrm{IO}_{3}\right)_{8} \mathrm{OH}$ (corresponding to the $\mathrm{La}\left(\mathrm{IO}_{3}\right)_{2.66}(\mathrm{OH})_{0.33}$ crystallographic asymmetric unit in the $\mathrm{P3C}$ space group) and $\mathrm{La}\left(\mathrm{IO}_{3}\right)_{2}\left(\mathrm{NO}_{3}\right)$ (corresponding to the $\mathrm{La}_{1.5}\left(\mathrm{IO}_{3}\right)_{3}\left(\mathrm{NO}_{3}\right)_{1.5}$ crystallographic asymmetric unit in the $P 3_{1} 21$ space group). However, they did not evidence any phase transformation from one structure to the other experimentally. ${ }^{26}$ 
$\alpha$ - $\mathrm{La}\left(\mathrm{IO}_{3}\right)_{3}$ micro-crystals were first obtained in solution from an hydrothermal method by $\mathrm{OK}$ et al. from $\mathrm{La}_{2} \mathrm{O}_{3}$ and $\mathrm{HIO}_{3}$ precursors dispersed in water with a $\left[\mathrm{La}^{3+}\right]:\left[\mathrm{IO}_{3}{ }^{-}\right]$molar ratio of 1:14 and heated at $220^{\circ} \mathrm{C}$ for several days (Table 1). M. Taouti et al. reproduced the hydrothermal conditions described by OK et al. but used $\mathrm{LaCl}_{3}$ and a $\mathrm{La}^{3+}: \mathrm{IO}_{3}{ }^{-}$molar ratio of $1: 4{ }^{27} \mathrm{We}$ recently synthesized $\alpha-\mathrm{La}\left(\mathrm{IO}_{3}\right)_{3}$ nanocrystals using a microwave-assisted (MW hydrothermal method, from $\mathrm{LaCl}_{3} \cdot 6 \mathrm{H}_{2} \mathrm{O}$ and $\mathrm{HIO}_{3}$ precursors dispersed in water with a $\mathrm{La}^{3+}: \mathrm{IO}_{3}{ }^{-}$molar ratio of $1: 3$ and heated at $250^{\circ} \mathrm{C}^{28}$ In the latter case, microwave heating was selected for its rapid heating rates, ${ }^{29,30,31}$ with the idea of decoupling the nucleation and growth stages, an essential procedure to obtain homogeneous and size-controlled nanocrystals for bio-imaging applications. Indeed, acentric $\alpha$ - $\mathrm{La}\left(\mathrm{IO}_{3}\right)_{3}$ nanocrystals, also called harmonic nanoparticles (HNP), could be used as bio-labelling nanoprobes like $\mathrm{BaTiO}_{3}{ }^{32}$ or $\mathrm{KTiOPO}_{4}{ }^{33}$ nanocrystals as they can be excited in the three biological transparency windows, circumventing the limitations (low penetration depth, photobleaching, blinking, optically resonant conditions, ...) encountered with most fluorescent probes. Moreover, compared to other known HNPs, $\alpha-\mathrm{La}\left(\mathrm{IO}_{3}\right)_{3}$ nanocrystals can be doped with lanthanide ions, demonstrating dual emission (SHG and photoluminescence). ${ }^{34}$

In this paper, we discuss how to obtain the optically-interesting and most stable $\alpha$-La $\left(\mathrm{IO}_{3}\right)_{3}$. Starting from precipitates obtained from the co-precipitation of $\mathrm{LaCl}_{3} \cdot 6 \mathrm{H}_{2} \mathrm{O}$ and $\mathrm{HIO}_{3}$ in water, we explore various synthesis conditions in solution, leading to the crystallization of different lanthanum iodate compounds. The synthesis conditions ( $\left[\mathrm{La}^{3+}\right]:\left[\mathrm{IO}_{3}{ }^{-}\right]$molar ratio, temperature of the hydrothermal process) result in the formation of $\alpha$ - $\mathrm{La}\left(\mathrm{IO}_{3}\right)_{3}$ or intermediate phases, namely $\mathrm{La}\left(\mathrm{IO}_{3}\right)_{3}\left(\mathrm{H}_{2} \mathrm{O}\right)$ and $\mathrm{La}\left(\mathrm{IO}_{3}\right)_{3}\left(\mathrm{HIO}_{3}\right)$. Phase transformations in solid-state or under $\mathrm{MW}$-assisted hydrothermal conditions are discussed, in light of the structural relationships between the different compounds. Furthermore, the new hydrate phase, $\mathrm{La}\left(\mathrm{IO}_{3}\right)_{3}\left(\mathrm{H}_{2} \mathrm{O}\right)$, is characterized by single-crystal X-ray diffraction, temperature-dependent powder $\mathrm{X}$-ray diffraction and thermal analysis.

\section{Experimental details}

\section{Hydrothermal synthesis of $\alpha-\mathrm{La}\left(\mathrm{IO}_{3}\right)_{3}, \mathrm{La}\left(\mathrm{IO}_{3}\right)_{3}\left(\mathrm{H}_{2} \mathrm{O}\right)$ and $\mathrm{La}\left(\mathrm{IO}_{3}\right)_{3} \mathrm{HIO}_{3}$}

Lanthanum(III) chloride hexahydrate $\left(\mathrm{LaCl}_{3} \cdot 6 \mathrm{H}_{2} \mathrm{O}\right.$, Strem Chemicals, 99.9\%) and iodic acid $\left(\mathrm{HIO}_{3}\right.$, Aldrich, 99.5\%) were used, without further purification, as precursors. $0.5 \mathrm{mmol}$ of $\mathrm{LaCl}_{3} \cdot 6 \mathrm{H}_{2} \mathrm{O}$ and $x$ mmol of $\mathrm{HIO}_{3}$ (where $x$ varies between 1.5 and $10 \mathrm{mmol}$, leading to a molar ratio of $\left[\mathrm{La}^{3+}\right]:\left[\mathrm{IO}_{3}{ }^{-}\right]$between 3 and 20) were, separately, dissolved into $10 \mathrm{~mL}$ of deionized water under weak stirring. Both solutions were then poured into a $80 \mathrm{~mL}$ quartz reactor, forming a white amorphous precipitate. The reactor was air-tightly closed and placed into a microwave (MW) oven (Anton Paar, Multiwave PRO SOLV, operating at a frequency of $2.45 \mathrm{GHz}$ ). The oven temperature was adjusted by setting the MW power between 0 and $900 \mathrm{~W}$. The pressure builds up inside the quartz vessel, autogenerated by the water phase transition.

\begin{tabular}{llll} 
Precursors & $\begin{array}{l}{\left[\mathrm{La}^{3+}\right]:\left[\mathrm{IO}_{3}{ }^{-}\right]} \\
\text {molar ratio }\end{array}$ & Synthesis method & Ref. \\
\hline $\mathrm{La}_{2} \mathrm{O}_{3}, \mathrm{HIO}_{3}$ & $1: 14$ & $\begin{array}{l}\text { Hydrothermal } \\
\text { treatment, 220 }\end{array}$ & {$[15]$} \\
& & $\begin{array}{l}\text { 4 days } \\
\text { Hydrothermal }\end{array}$ & {$[27]$} \\
$\mathrm{LaCl}_{3} \cdot 6 \mathrm{H}_{2} \mathrm{O}$, & $1: 4$ & $\begin{array}{l}\text { treatment, 220 } \\
\text { 4 } \mathrm{C},\end{array}$ & \\
$\mathrm{HIO}_{3}$ & & $\begin{array}{l}\text { days } \\
\text { MW-assisted }\end{array}$ & [28] \\
$\mathrm{LaCl}_{3} \cdot 6 \mathrm{H}_{2} \mathrm{O}$, & $1: 3$ & $\begin{array}{l}\text { hydrothermal } \\
\text { treatment, 250 }\end{array}$ & \\
$\mathrm{HIO}_{3} \mathrm{C} \mathrm{C}, 1$ & \\
& & hour
\end{tabular}

Table 1. Summary of different synthesis conditions leading to the formation of SHG-active $\alpha-\mathrm{La}\left(\mathrm{IO}_{3}\right)_{3}$ phase.

The efficient coupling of the MWs with the species present inside the quartz vessel (solvent and precursors) allows a rapid heating $\left(\sim 30^{\circ} \mathrm{C} \mathrm{min}{ }^{-1}\right)$. Indeed, the more polar the species, the higher their ability to convert electromagnetic energy into heat, leading to efficient $\mathrm{MW}$-assisted heating. ${ }^{35}$ However, it is worth noting that the $\mathrm{MW}$ heating is very sensitive to the precursor nature, purity and concentration, influencing the synthesis temperature. ${ }^{36}$

The MW program used for the synthesis of the different lanthanum iodates is detailed in Supplementary Information file (Figures S1 \& S2). According to the $\left[\mathrm{La}^{3+}\right]$ : $\left[\mathrm{IO}_{3}{ }^{-}\right]$molar ratio, the temperature inside the reactor varies: when the $\mathrm{HIO}_{3}$ concentration is high, more energy is required to heat the mixture. Therefore, for the same MW power, the temperature inside the reactor is lower.

A white power was obtained in the quartz reactor, along with a yellowish supernatant resulting from the decomposition of $\mathrm{HIO}_{3}$. The obtained precipitate was filtered (round filter, type $14 \mathrm{~A}$ - cellulose, membrane diameter $125 \mathrm{~mm}$ ), washed with water and dried at room temperature for 1 day. Depending of the $\left[\mathrm{La}^{3+}\right]:\left[\mathrm{IO}_{3}{ }^{-}\right]$molar ratio and the maximal synthesis temperature, different phases, characterized by X-ray diffraction, were obtained: $\alpha-\mathrm{La}\left(\mathrm{IO}_{3}\right)_{3}, \quad \mathrm{La}\left(\mathrm{IO}_{3}\right)_{3}\left(\mathrm{H}_{2} \mathrm{O}\right)$ and $\mathrm{La}\left(\mathrm{IO}_{3}\right)_{3}\left(\mathrm{HIO}_{3}\right)$ with a reaction yield of $85 \% \pm 10 \%$.

\section{Phase transformation under MW-assisted hydrothermal conditions}

$\mathrm{La}\left(\mathrm{IO}_{3}\right)_{3}\left(\mathrm{H}_{2} \mathrm{O}\right)$ was dispersed into water $(\mathrm{V}=20 \mathrm{~mL})$ with a concentration of $10 \mathrm{~g} \mathrm{~L}^{-1}$. The solution was then placed into a quartz vessel. The $\mathrm{MW}$ oven was programmed so that the temperature reaches $250^{\circ} \mathrm{C}$ and remains constant for different amounts of time ( $7 \mathrm{~min}$ and $10 \mathrm{~min}$ ) before cooling down (MW program detailed in Figure S3). The obtained powders, retrieved by filtration, characterized by powder XRD, were 
$\mathrm{La}\left(\mathrm{IO}_{3}\right)_{2.66}(\mathrm{OH})_{0.33}{ }^{26}$ and $\alpha$ - $\mathrm{La}\left(\mathrm{IO}_{3}\right)_{3}$ according to the reaction time, with a reaction yield of $60 \% \pm 10 \%$.

In recent work, ${ }^{26} \mathrm{La}\left(\mathrm{IO}_{3}\right)_{2.66}(\mathrm{OH})_{0.33}$ crystals have been obtained through hydrothermal method using a La:I stoichiometric ratio slightly inferior to the 1:3. A mixture of $\mathrm{La}\left(\mathrm{NO}_{3}\right)_{3} \cdot 6 \mathrm{H}_{2} \mathrm{O}$ (259.8 mg, $0.6 \mathrm{mmol}$ ), $\mathrm{I}_{2} \mathrm{O}_{5}(1168 \mathrm{mg}, 3.5 \mathrm{mmol}$ ), and $2 \mathrm{~mL} 10 \%$ $\mathrm{HF}$ solution was placed in a $23 \mathrm{~mL}$ Teflon-lined autoclave (molar ratio La:l equal to 1:2.92). The autoclaves were heated to $230^{\circ} \mathrm{C}$ in $6 \mathrm{~h}$, held for 3 days, and then cooled to $30^{\circ} \mathrm{C}$ at a rate of $3^{\circ} \mathrm{C} . \mathrm{h}^{-1}$.

When we dispersed $\mathrm{La}\left(\mathrm{IO}_{3}\right)_{2.66}(\mathrm{OH})_{0.33}$ into $20 \mathrm{~mL}$ of water with $\mathrm{HIO}_{3}$ (1 molar equivalent), the mixture should be heated at $250^{\circ} \mathrm{C}$ for $30 \mathrm{~min}$ to obtain $\alpha-\mathrm{La}\left(\mathrm{IO}_{3}\right)_{3}$ after cooling down (Figure S4).

\section{Crystal structure determination of $\mathrm{La}\left(\mathrm{IO}_{3}\right)_{3}\left(\mathrm{H}_{2} \mathrm{O}\right)$}

A new phase, $\mathrm{La}\left(\mathrm{IO}_{3}\right)_{3}\left(\mathrm{H}_{2} \mathrm{O}\right)$, was obtained from the $\mathrm{MW}$-assisted hydrothermal treatment of $\mathrm{LaCl}_{3} \cdot 6 \mathrm{H}_{2} \mathrm{O}$ and $\mathrm{HIO}_{3}$ in a $\left[\mathrm{La}^{3+}\right]:\left[\mathrm{IO}_{3}{ }^{-}\right]$molar ratio of $1: 10$. However, the obtained powder was very fine. This phase was identified by comparison of calculated powder XRD patterns issued of our previous works, ${ }^{37}$ and good refinement by LeBail method was obtained (Figure S3). $\mathrm{La}\left(\mathrm{IO}_{3}\right)_{3}\left(\mathrm{H}_{2} \mathrm{O}\right)$ single crystals were obtained by hydrothermal treatment in a Teflon lined autoclave of $\beta$ - $\mathrm{La}\left(\mathrm{IO}_{3}\right)_{3}$ in water at $120^{\circ} \mathrm{C}$ for 24 hours, followed by a rapid cooling. A single-crystal was mounted onto a Nonius CCD diffractometer, using $\mathrm{Ag} \mathrm{K} \alpha$ radiation $(\lambda=0.56087 \AA$ ) at $293 \mathrm{~K}$. The reflections were corrected for Lorentz and polarization effects. An absorption correction was applied using the empirical method. All structures were solved by direct methods with SIR92 program $^{38}$ and refined by full matrix least-squares, based on $\mathrm{F}^{2}$, using the Shelxl software ${ }^{39}$ through the WinGX program suite. ${ }^{40}$ Final refinement was performed with anisotropic thermal parameters for all atoms (Hydrogen atoms of water molecule were not localized). Crystal data of $\mathrm{La}\left(\mathrm{IO}_{3}\right)_{3}\left(\mathrm{H}_{2} \mathrm{O}\right)$ are summarized in Table 2. Further details of the crystal structure investigations may be obtained from the Fachinformationszentrum Karlsruhe, 76344 EggensteinLeopoldshafen, Germany, on quoting the depository number CSD-1973253.

\begin{tabular}{ll} 
Parameter & $\mathrm{La}\left(\mathrm{IO}_{3}\right)_{3}\left(\mathrm{H}_{2} \mathrm{O}\right)$ \\
\hline $\mathrm{M}\left(\mathrm{g} \mathrm{mol}{ }^{-1}\right)$ & 681.61 \\
crystal system & Monoclinic \\
space group $\left(\mathrm{n}^{\circ}\right)$ & $P 2_{1} / n(14)$ \\
$a(\AA)$ & $7.177(1)$ \\
$b(\AA)$ & $13.260(1)$ \\
$c(\AA \AA)$ & $9.786(1)$ \\
$B\left(\left(^{\circ}\right)\right.$ & $100.09(1)$ \\
$V\left(\AA^{3}\right)$ & $916.9(2)$ \\
$Z$ & 4 \\
$D_{X}\left(g \mathrm{~cm}^{-3}\right)$ & 4.923 \\
$\lambda(A g K \alpha)$ & 0.56087 \\
$\mu\left(m m^{-1}\right)$ & 7.827 \\
$R_{1}(I>2 \sigma(I))^{a}$ & 0.024 \\
$w R_{2}^{b}$ & 0.044 \\
${ }^{\mathrm{a}} \mathrm{R}_{1}=\Sigma\|\mathrm{Fo}|-| \mathrm{Fc}\| / \Sigma \mid \mathrm{Fol},{ }^{b} \omega \mathrm{R}_{2}=\left[\Sigma\left(\omega\left(\mathrm{Fo}^{2}-\mathrm{Fo}^{2}\right)^{2}\right) / \Sigma\left(\omega\left(\mathrm{Fo}^{2}\right)^{2}\right]^{1 / 2}\right.$ \\
\end{tabular}

Table 2. Crystal data for $\mathrm{La}\left(\mathrm{IO}_{3}\right)_{3}\left(\mathrm{H}_{2} \mathrm{O}\right)$

\section{Powder X-ray diffraction pattern}

Powder X-ray diffraction (PXRD) patterns of the different lanthanum iodate compounds were recorded under ambient conditions, using a Siemens D8 Advance diffractometer with $\mathrm{Cu} K \alpha_{1}$ radiation $(\lambda=1.54056 \AA, 40 \mathrm{~mA}, 40 \mathrm{kV})$ in the $2 \theta=15-100^{\circ}$ range, with a 0.01 step size and an acquisition of 6 s per step.

Further in situ temperature dependent XRD experiments were recorded to study the structural evolution of the newly reported $\mathrm{La}\left(\mathrm{IO}_{3}\right)_{3}\left(\mathrm{H}_{2} \mathrm{O}\right)$ phase. XRD patterns were recorded using a Co $K \alpha_{1}$ anode (1.78897 $\AA$ ) in helium atmosphere, in the $2 \theta=15-100^{\circ}$ range, every $2 \mathrm{~min}$, between room temperature and $450^{\circ} \mathrm{C}$. The heating and cooling rate were both $1^{\circ} \mathrm{C} \mathrm{min}^{-1}$.

\section{Thermal Analysis}

Thermal analyses were performed on a Netzsch Model DTA-DSC 404S apparatus for differential scanning analysis (DSC-TG). The thermal measurements of amorphous precipitates and lanthanum iodate phases were carried out in the $80-480^{\circ} \mathrm{C}$ range, in argon flow at $10^{\circ} \mathrm{C} \mathrm{min}^{-1}$ for heating and cooling rate.

\section{Results and discussion}

Crystallization of lanthanum iodates in solution, under hydrothermal conditions

We present here the crystallization in water of amorphous precipitates resulting from the co-precipitation of $\mathrm{LaCl}_{3} \cdot 6 \mathrm{H}_{2} \mathrm{O}$ 
and $\mathrm{HIO}_{3}$ in different molar ratios $\left(\left[\mathrm{La}^{3+}\right]:\left[\mathrm{IO}_{3}{ }^{-}\right]=1: 3,1: 10\right.$ and 1:20). The precipitates in water were placed in a quartz reactor and placed inside the MW oven programmed as indicated in Figures S1 \& S2.

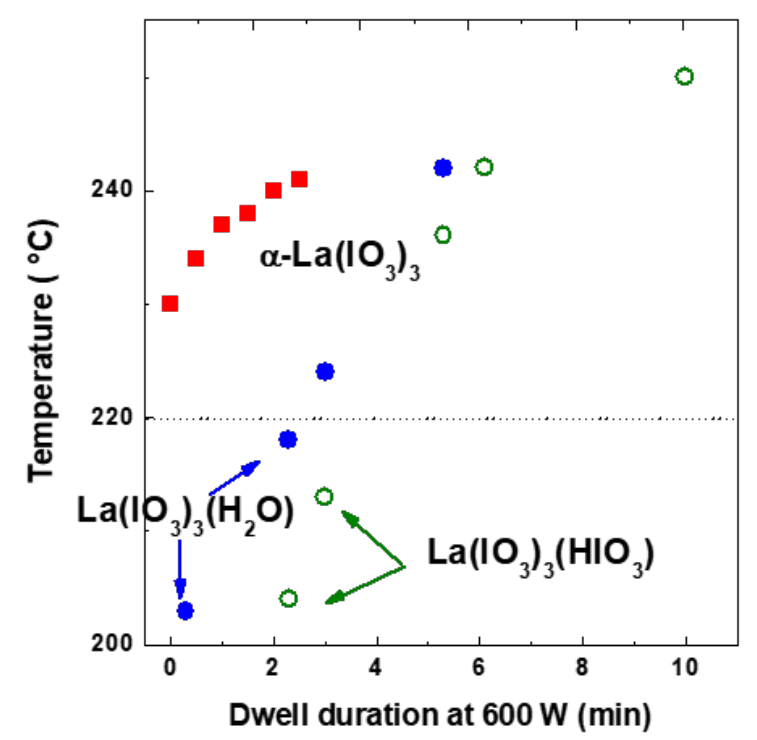

Figure 1. Evolution of the maximal synthesis temperature as a function of the dwell duration at $600 \mathrm{~W}$, for different molar ratio $\left[\mathrm{La}^{3+}\right]:\left[\mathrm{IO}_{3}{ }^{-}\right]=1: 3(\cdot), 1: 10(\bullet)$ and 1:20 (०). The obtained crystal phase is indicated on the graph. The dotted line symbolizes the minimal temperature required for the crystallization of $\alpha-\mathrm{La}\left(\mathrm{IO}_{3}\right)_{3}$.

The temperature and pressure inside the $\mathrm{MW}$ oven change according to the different molar ratios $\left(\left[\mathrm{La}^{3+}\right]:\left[\mathrm{IO}_{3}{ }^{-}\right]\right.$, influencing the nature of the crystallized compound obtained at the end of the hydrothermal synthesis (Figure 1). For a $\left[\mathrm{La}^{3+}\right]:\left[\mathrm{IO}_{3}{ }^{-}\right]$molar ratio of $1: 3$, the temperature increases rapidly and reaches $230^{\circ} \mathrm{C}$ at the beginning of the dwell at $600 \mathrm{~W}$. Hence, whatever the duration of the dwell at $600 \mathrm{~W}, \alpha-\mathrm{La}\left(\mathrm{IO}_{3}\right)_{3}$ phase is crystallized (red squares, Figure 1). For $\left[\mathrm{La}^{3+}\right]:\left[\mathrm{IO}_{3}{ }^{-}\right]$molar ratios of $1: 10$ and 1:20, the temperature is much lower at the beginning of the dwell at $600 \mathrm{~W}$ (blue and green dots, Figure 1). Consequently, if the synthesis is stopped at the beginning of the third dwell, $\mathrm{La}\left(\mathrm{IO}_{3}\right)_{3}\left(\mathrm{H}_{2} \mathrm{O}\right)$ and $\mathrm{La}\left(\mathrm{IO}_{3}\right)_{3}\left(\mathrm{HIO}_{3}\right)$ phases are crystallized. If the synthesis duration is lengthened, enabling the system to heat above $220^{\circ} \mathrm{C}$, the reaction product is $\alpha-\mathrm{La}\left(\mathrm{IO}_{3}\right)_{3}$. It is important to note that for a $\left[\mathrm{La}^{3+}\right]:\left[\mathrm{IO}_{3}{ }^{-}\right]$molar ratio of $1: 3$, if the $\mathrm{MW}$-assisted hydrothermal synthesis is stopped before reaching the temperature of $220^{\circ} \mathrm{C}$ (i.e. during the second step of the MW program), the $\mathrm{La}\left(\mathrm{IO}_{3}\right)_{3}\left(\mathrm{H}_{2} \mathrm{O}\right)$ hydrated phase is obtained.

Hence, from Figure 1, it is clear that, if the synthesis temperature remains below $220^{\circ} \mathrm{C}$, intermediate lanthanum iodates are formed, namely $\mathrm{La}\left(\mathrm{IO}_{3}\right)_{3}\left(\mathrm{H}_{2} \mathrm{O}\right)$ and $\mathrm{La}\left(\mathrm{IO}_{3}\right)_{3}\left(\mathrm{HIO}_{3}\right)$. For higher synthesis temperature, $\alpha$ - $\mathrm{La}\left(\mathrm{IO}_{3}\right)_{3}$ crystallizes. All PXRD diagrams are included in the Supplementary Information file (Figure S4). Different iodate compounds can be obtained from the co-precipitation of $\mathrm{La}^{3+}$ and $\mathrm{IO}_{3}{ }^{-}$in solution followed by a hydrothermal treatment, when controlling the synthesis temperature.
Previously, the synthesis of $\mathrm{La}\left(\mathrm{IO}_{3}\right)_{3}\left(\mathrm{HIO}_{3}\right)$ was reported by slow evaporation of a solution of $\mathrm{LaCl}_{3} \cdot 6 \mathrm{H}_{2} \mathrm{O}$ and $\mathrm{KIO}_{3}$ in a molar ratio of 5 at $50^{\circ} \mathrm{C},{ }^{41}$ whereas $\alpha$ - $\mathrm{La}\left(\mathrm{IO}_{3}\right)_{3}$ was crystallized by hydrothermal method at $220^{\circ} \mathrm{C}$. Our study is in good agreement with those findings and furthermore shows that $\alpha-\mathrm{La}\left(\mathrm{IO}_{3}\right)_{3}$ requires more energy for crystallization.

Hence, $\alpha-\mathrm{La}\left(\mathrm{IO}_{3}\right)_{3}$ can be obtained by $\mathrm{MW}$-assisted hydrothermal synthesis, beyond $220^{\circ} \mathrm{C}$, from different molar ratios of $\left[\mathrm{La}^{3+}\right]:\left[\mathrm{IO}_{3}{ }^{-}\right]$. Note that, with such a synthesis method, the $\alpha$ - $\mathrm{La}\left(\mathrm{IO}_{3}\right)_{3}$ phase crystallizes as nanocrystals (Figure S5), which could be used as nanoprobes in bio-imaging. ${ }^{28}$ Hereafter we explore phase transformation in solid state or in hydrothermal conditions, with the goal of obtaining $\alpha-\mathrm{La}\left(\mathrm{IO}_{3}\right)_{3}$ from other lanthanum iodate compounds.

\section{Phase transformation in solid state}

To characterize the amorphous precipitates resulting from the different $\left[\mathrm{La}^{3+}\right]:\left[\mathrm{IO}_{3}{ }^{-}\right]$molar ratios $(1: 3,1: 10$ and 1:20), DSC-TG analyses were performed and showed different thermal behaviors with lanthanum iodate phase transformations in solid state (Figure 2). For all analyses, a dwell of 4 hours at $50^{\circ} \mathrm{C}$ was set up to remove all water molecules adsorbed at the surface of the precipitates (between $2 \%$ and $6 \%$ mass loss on TG curves below $50^{\circ} \mathrm{C}$ ). For $\left[\mathrm{La}^{3+}\right]:\left[1 \mathrm{O}_{3}{ }^{-}\right]=1: 3$, between $50^{\circ} \mathrm{C}$ to $300^{\circ} \mathrm{C}$, one can observe the departure of one solvated water molecule in the precipitate (ca. $2.6 \%$ weight loss on TG curves, Figure 2a). The amorphous precipitate crystallizes at $350^{\circ} \mathrm{C}$ (peak at $366^{\circ} \mathrm{C}$ ) in $\mathrm{La}\left(\mathrm{IO}_{3}\right)_{3}$, subsequently identified as $\gamma$ - $\mathrm{La}\left(\mathrm{IO}_{3}\right)_{3}$, that then partially transforms into $\beta$ - $\mathrm{La}\left(\mathrm{IO}_{3}\right)_{3}$ at $127^{\circ} \mathrm{C}$ (peak at $120^{\circ} \mathrm{C}$ ) upon cooling. ${ }^{27}$ The reversible phase transformation $\beta$ to $\gamma$ is mainly associated with the breaking of $\mathrm{La}-\mathrm{O}$ bond and the rotation of an $\mathrm{IO}_{3}^{-}$group. ${ }^{27}$ For $\left[\mathrm{La}^{3+}\right]:\left[1 \mathrm{O}_{3}{ }^{\circ}\right]=1: 10$, between $50^{\circ} \mathrm{C}$ to $300^{\circ} \mathrm{C}$, the mass loss corresponds to the departure of two solvated water molecules in the precipitate ( $c a .5 \%$ mass loss on TG curves, Figure $\mathbf{2 b}$ ). The precipitate crystallizes at $293^{\circ} \mathrm{C}$ (peak at $309^{\circ} \mathrm{C}$ ) in $\mathrm{La}\left(\mathrm{IO}_{3}\right)_{3}\left(\mathrm{HIO}_{3}\right)$. This phase then transforms into $\mathrm{La}\left(\mathrm{IO}_{3}\right)_{3}$ with the departure of one $\mathrm{HIO}_{3}$ molecule (weight loss of $14 \%$, TG curve), as shown by the presence of an endothermic peak at $380^{\circ} \mathrm{C}$ (peak at $410^{\circ} \mathrm{C}$ ). Another crystallization peak at $460^{\circ} \mathrm{C}$ (peak at $473^{\circ} \mathrm{C}$ ) without weight loss is observed. This $\mathrm{La}\left(\mathrm{IO}_{3}\right)_{3}$ phase was further identified as $\mathrm{\gamma}-\mathrm{La}\left(\mathrm{IO}_{3}\right)_{3}$, which transforms into $\beta$ - $\mathrm{La}\left(\mathrm{IO}_{3}\right)_{3}$ upon cooling. For a $\left[\mathrm{La}^{3+}\right]:\left[\mathrm{IO}_{3}{ }^{-}\right]=1: 20$, the departure of one solvated water molecule is observed between 50 and $300^{\circ} \mathrm{C}$ (Figure $\mathbf{2 c}$ ). The precipitate crystallizes into $\mathrm{La}\left(\mathrm{IO}_{3}\right)_{3}\left(\mathrm{HIO}_{3}\right)_{1.33}$ at $290^{\circ} \mathrm{C}$ (peak at $301^{\circ} \mathrm{C}$ ), showing that the excess of iodic acid contributes to an $\mathrm{HIO}_{3}$-enriched phase. Upon heat treatment, an endothermic peak at $488^{\circ} \mathrm{C}$ is observed, in parallel to the departure of $1.33 \mathrm{HIO}_{3}$ molecules (weight loss of $17 \%$, TG curve). The obtained phase has been subsequently identified as $\mathrm{Y}-\mathrm{La}\left(\mathrm{IO}_{3}\right)_{3}$.

This study, performed in solid state, evidences the formation of different lanthanum iodate phases, according to the nature of the initial precipitate which plays a major role in the formation of the different compounds. Various phase transformations in solid state are highlighted, consistently with the previous study of Suffren et al, ${ }^{27}$ however, none of these 
phase changes leads to the formation of $\alpha$ - $\mathrm{La}\left(\mathrm{IO}_{3}\right)_{3}$. Furthermore, this study shows that the nature of amorphous precipitates depends of the initial used $\left[\mathrm{La}^{3+}\right]:\left[\mathrm{IO}_{3}{ }^{-}\right]$ratio. These amorphous precipitates are all hydraded and correspond to $\mathrm{La}\left(\mathrm{IO}_{3}\right)_{3} \cdot \mathrm{H}_{2} \mathrm{O}, \mathrm{La}\left(\mathrm{IO}_{3}\right)_{3}\left(\mathrm{HIO}_{3}\right) \cdot \mathrm{H}_{2} \mathrm{O}$ and $\mathrm{La}\left(\mathrm{IO}_{3}\right)_{3}\left(\mathrm{HIO}_{3}\right)_{1.33} \cdot \mathrm{H}_{2} \mathrm{O}$ for a $\left[\mathrm{La}^{3+}\right]:\left[\mathrm{IO}_{3}{ }^{-}\right]=1: 3 ; 1: 10$ and $1: 20$, respectively. 

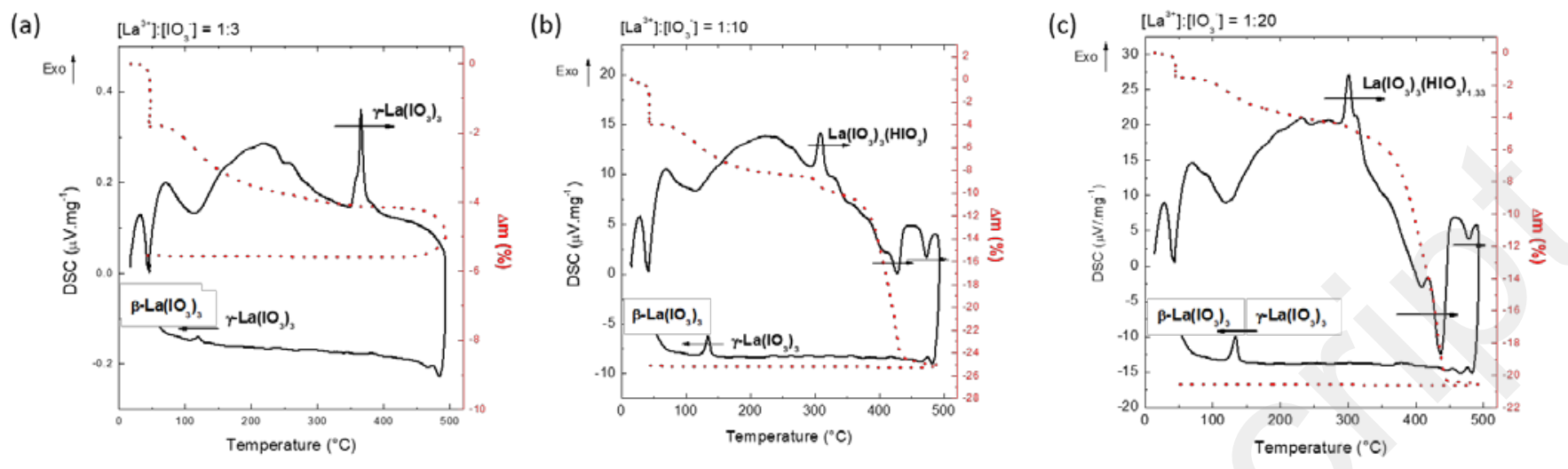

Figure 2: DSC (black curves) and TG (red dotted curves) analyses of the amorphous precipitates resulting from a $\left[\mathrm{La}^{3+}\right]:\left[1 \mathrm{O}_{3}{ }^{-}\right]$molar ratio of (a) $1: 3$, (b) $1: 10$ and (c) $1: 20$ versus temperature between $20^{\circ} \mathrm{C}$ and $480^{\circ} \mathrm{C}$, under inert atmosphere (scanning rate: $10^{\circ} \mathrm{C} . \mathrm{min}^{-1}$, upon heating and cooling).

It is worth noting that, starting from an amorphous precipitate obtained for a given $\left[\mathrm{La}^{3+}\right]:\left[\mathrm{IO}_{3}{ }^{-}\right]$ratio, the $\mathrm{MW}$-assisted hydrothermal route leads to a crystalline compound different from the one obtained through solid-state reaction. Thus, for a $\left[\mathrm{La}^{3+}\right]:\left[\mathrm{IO}_{3}{ }^{-}\right]$ratio of $1: 3$ and $1: 10$, the hydrothermal method leads to $\mathrm{La}\left(\mathrm{IO}_{3}\right)_{3}\left(\mathrm{H}_{2} \mathrm{O}\right)$ for a synthesis temperature below $220^{\circ} \mathrm{C}$ and to $\alpha-\mathrm{La}\left(\mathrm{IO}_{3}\right)_{3}$ for $\mathrm{T}>220^{\circ} \mathrm{C}$, whereas the solid-state reaction leads to $\gamma$ - $\mathrm{La}\left(\mathrm{IO}_{3}\right)_{3}$ and $\mathrm{La}\left(\mathrm{IO}_{3}\right)_{3}\left(\mathrm{HIO}_{3}\right)$ after heating at $350^{\circ} \mathrm{C}$ and $300^{\circ} \mathrm{C}$, respectively. For a $\left[\mathrm{La}^{3+}\right]:\left[\mathrm{IO}_{3}{ }^{-}\right]$ratio of $1: 20$, the hydrothermal method leads to $\mathrm{La}\left(\mathrm{IO}_{3}\right)_{3}\left(\mathrm{HIO}_{3}\right)$ for a synthesis temperature below $220^{\circ} \mathrm{C}$ and to $\alpha-\mathrm{La}\left(\mathrm{IO}_{3}\right)_{3}$ for $\mathrm{T}>220^{\circ} \mathrm{C}$, whereas the solid-state reaction leads to $\mathrm{La}\left(\mathrm{IO}_{3}\right)_{3}\left(\mathrm{HIO}_{3}\right)_{1.33}$ after heating at $300^{\circ} \mathrm{C}$. The crystallization of various lanthanum iodate compounds not only depends on the synthesis temperature but also on the synthesis medium.

\section{Phase transformation in solution, under hydrothermal conditions}

$\mathrm{La}\left(\mathrm{IO}_{3}\right)_{3}\left(\mathrm{H}_{2} \mathrm{O}\right)$ was dispersed in water and treated under hydrothermal conditions. If the $\mathrm{MW}$ program previously detailed (Figure S1) is applied to this mixture (crystalline $\mathrm{La}\left(\mathrm{IO}_{3}\right)_{3}\left(\mathrm{H}_{2} \mathrm{O}\right)$ in water), the temperature does not reach $220^{\circ} \mathrm{C}$. It is due to the crystalline nature of $\mathrm{La}\left(\mathrm{IO}_{3}\right)_{3}\left(\mathrm{H}_{2} \mathrm{O}\right)$ phase (vs. amorphous precipitate in the previous case), which requires more energy. The MW program was adjusted in order to reach temperatures above $220^{\circ} \mathrm{C}$, corresponding to the minimal temperature required for the crystallization of $\alpha-\mathrm{La}\left(\mathrm{IO}_{3}\right)_{3}$ (Figure S6). When $\mathrm{La}\left(\mathrm{IO}_{3}\right)_{3}\left(\mathrm{H}_{2} \mathrm{O}\right)$ is heated at $250^{\circ} \mathrm{C}$ for $7 \mathrm{~min}$ under hydrothermal conditions and cooled down, a reaction intermediate is obtained, characterized by XRD as $\mathrm{La}\left(\mathrm{IO}_{3}\right)_{2.66}(\mathrm{OH})_{0.33}{ }^{26}$ For a hydrothermal treatment of $10 \mathrm{~min}$ at $250^{\circ} \mathrm{C}, \alpha-\mathrm{La}\left(\mathrm{IO}_{3}\right)_{3}$ is obtained. This is the first evidence of a transformation from a lanthanum iodate compound (hydrate lanthanum iodate) into acentric $\alpha-\mathrm{La}\left(\mathrm{IO}_{3}\right)$.

In addition, when dispersing $\mathrm{La}\left(\mathrm{IO}_{3}\right)_{2.66}(\mathrm{OH})_{0.33}$ in water with one molar equivalent of $\mathrm{HIO}_{3}$ and applying a hydrothermal treatment at $250^{\circ} \mathrm{C}$ for $20 \mathrm{~min}$ (MW program shown in Figure S7), $\alpha-\mathrm{La}\left(\mathrm{IO}_{3}\right)_{3}$ is also obtained. Hence, the total phase transformation can be described as:

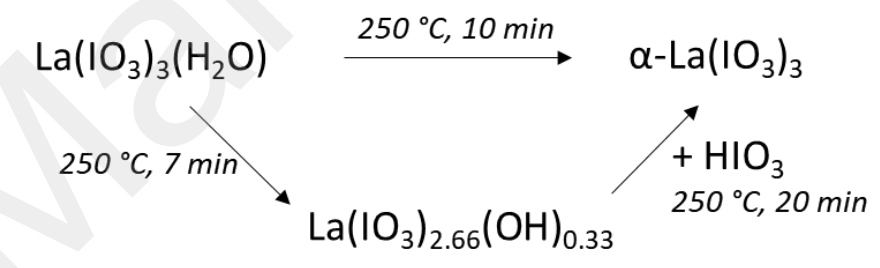

where the $\mathrm{La}\left(\mathrm{IO}_{3}\right)_{2.66}(\mathrm{OH})_{0.33}$ compound is the reaction intermediate of $\alpha$ - $\mathrm{La}\left(\mathrm{IO}_{3}\right)_{3}$ starting from $\mathrm{La}\left(\mathrm{IO}_{3}\right)_{3}\left(\mathrm{H}_{2} \mathrm{O}\right)$. Note that Mao et al. obtained $\mathrm{La}\left(\mathrm{IO}_{3}\right)_{2.66}(\mathrm{OH})_{0.33}$ crystals through hydrothermal method at $230^{\circ} \mathrm{C}$ with a sub-stoichiometric La:I ratio. ${ }^{26}$ Although the temperature could have enabled to crystallize the $\alpha$ - $\mathrm{La}\left(\mathrm{IO}_{3}\right)_{3}$ phase, the La:I ratio inferior to $1: 3$ could explain why they did not get the $\alpha-\mathrm{La}\left(\mathrm{IO}_{3}\right)_{3}$ phase.

\section{Crystal Structure of $\mathrm{La}\left(\mathrm{IO}_{3}\right)_{3}\left(\mathrm{H}_{2} \mathrm{O}\right)$}

This study based on hydrothermal synthesis of lanthanum iodates led to the discovery of a new compound, $\mathrm{La}\left(\mathrm{IO}_{3}\right)_{3}\left(\mathrm{H}_{2} \mathrm{O}\right)$. Its structure has been characterized by $\mathrm{X}$-ray diffraction on a single-crystal and reveals that $\mathrm{La}\left(\mathrm{IO}_{3}\right)_{3}\left(\mathrm{H}_{2} \mathrm{O}\right)$ crystallizes in the $P 2_{1} / n$ monoclinic space group.

The asymmetric unit consists of one lanthanum, three iodate anions and one water molecule in general positions (Figure 3a). The crystal structure reveals a three-dimensional network with $\mathrm{LaO}_{9}$ lanthanum polyhedra, linked together by bridging iodate groups (Figure 3a). Note that the presence of water has been confirmed by FTIR spectroscopy (Figure S8). 
(a)

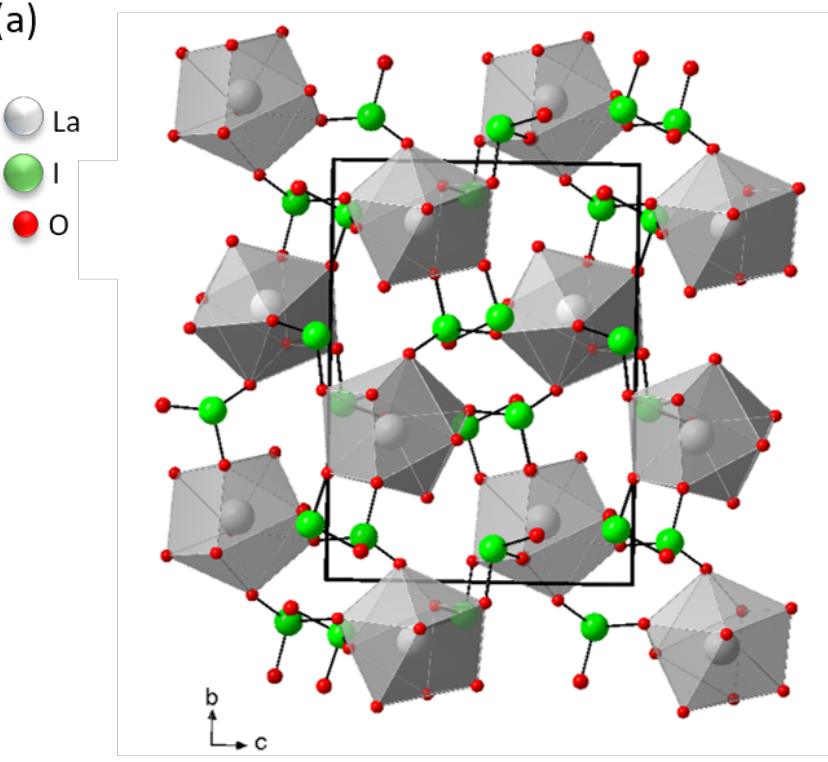

(b)

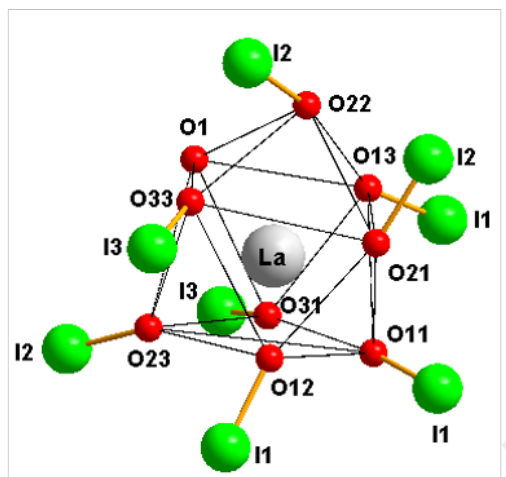

Figure 3. a) Projection of the $3 \mathrm{D}$ crystal structure of $\mathrm{La}\left(\mathrm{IO}_{3}\right)_{3}\left(\mathrm{H}_{2} \mathrm{O}\right)$ in the $(100)$ plane b) View of the coordination polyhedron around $\mathrm{La}^{3+}$ ion.

The lanthanum ion is coordinated to nine oxygen atoms provided by eight iodate groups (three $\mathrm{I}(1) \mathrm{O}_{3}$, three $\mathrm{I}(2) \mathrm{O}_{3}$, two $\mathrm{I}\left(3 \mathrm{O}_{3}\right)$ and one water molecule (O1). The corresponding calculated bond valence sum is 3.12 (Figure 3b). ${ }^{42,43,44}$ Eight La-O bond lengths are ranged from 2.473(4) to 2.575(4) $\AA$ and a longer ninth bond length ( $\mathrm{La}-\mathrm{O} 22=2.883(4) \AA ̊$ ) (Table 3). So, the coordination polyhedron may be described as a monocapped Archimedean antiprism. The dihedral angle between the two square plans defined by (011 012023031$)$ and $(021033 \mathrm{O} 1 \mathrm{O} 13)$ is $6.0(2)^{\circ}$. Each La atom is surrounded by eleven La neighbors via bis-monodentate iodate bridges with La $\cdots$ La metal distances in the range of $6.190(1)-7.177(1) \AA$. The environments of the iodine atoms in the three iodate groups are formed by three strong bonds (bond length range: $1.803(4)$ - 1.833(4) $\AA$ ), corresponding to an $\mathrm{AX}_{3} \mathrm{E}$ configuration. For $\mathrm{I} 1$ and $\mathrm{I} 3$ atoms, three interactions (2.738(4) - 3.230(4) A) complete their coordination, leading to distorted octahedral geometries around iodine atoms. For 12, only two interactions complete the coordination sphere (2.697(4) $\AA$ and 2.709(4) $\AA$ ). lodate groups coordinate either three La atoms in a tris-monodentate way via 011, 012, 013,
$\mathrm{O} 21, \mathrm{O} 22$ and $\mathrm{O} 23$ or two La atoms in a bis-monodentate way via $\mathrm{O} 31$ and $\mathrm{O} 33, \mathrm{O} 32$ being free.

\section{Thermal Behavior of $\mathrm{La}\left(\mathrm{IO}_{3}\right)_{3}\left(\mathrm{H}_{2} \mathrm{O}\right)$}

DSC-TG analysis of $\mathrm{La}\left(\mathrm{IO}_{3}\right)_{3}\left(\mathrm{H}_{2} \mathrm{O}\right)$ shows a sharp endothermic peak (onset at $313^{\circ} \mathrm{C}, \max$ at $325^{\circ} \mathrm{C}$ ), corresponding to a weight loss of $2.7 \%$ (TG curve) attributed to the departure of one strongly coordinated $\mathrm{H}_{2} \mathrm{O}$ molecule (Figure 4a). This is in good agreement with the temperature-dependent XRD patterns, showing a sudden phase transformation at $300^{\circ} \mathrm{C}$ from $\mathrm{La}\left(\mathrm{IO}_{3}\right)_{3}\left(\mathrm{H}_{2} \mathrm{O}\right)$ to $\mathrm{Y}$ - $\mathrm{La}\left(\mathrm{IO}_{3}\right)_{3}$ (Figure 4b). During the cooling, an exothermic peak is observed at $134^{\circ} \mathrm{C}\left(\max\right.$ at $\left.123^{\circ} \mathrm{C}\right)$ on the DSC-TG curve, corresponding to the transformation $\gamma-\mathrm{La}\left(\mathrm{IO}_{3}\right)_{3}$ to $\beta$ - La $\left(\mathrm{IO}_{3}\right)_{3}$, as confirmed by the XRD patterns (Figure $4 \mathbf{b}$ ). ${ }^{22}$ These two phases (centric $\gamma$ - $\mathrm{La}\left(\mathrm{IO}_{3}\right)_{3}$ and acentric $\beta$ - $\left.\mathrm{La}\left(\mathrm{IO}_{3}\right)_{3}\right)$ have very close structures (Table $\mathbf{S 1}$ ) as mentioned above. 
(a)

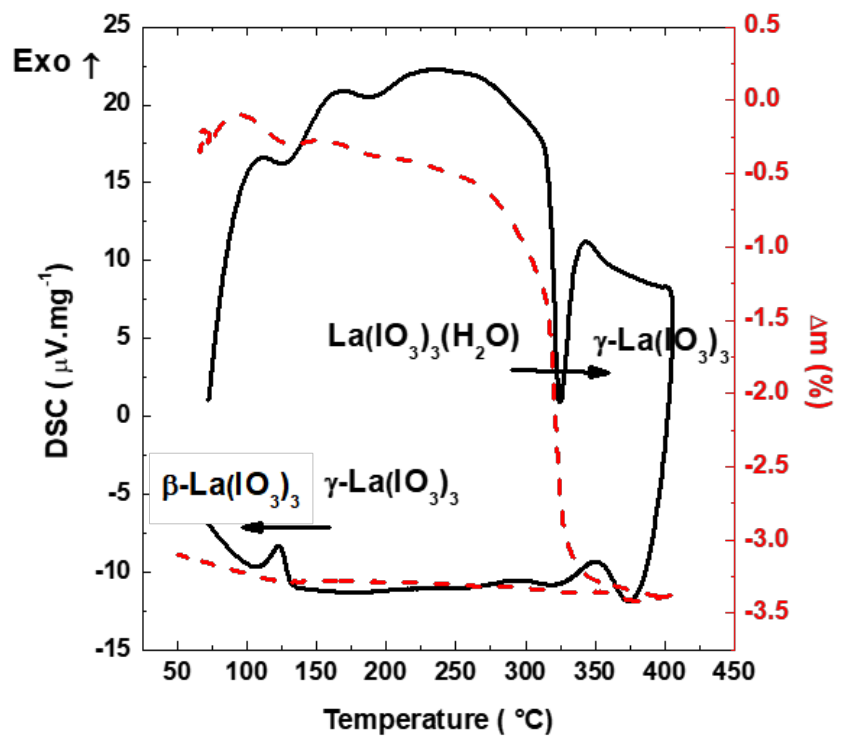

(b)

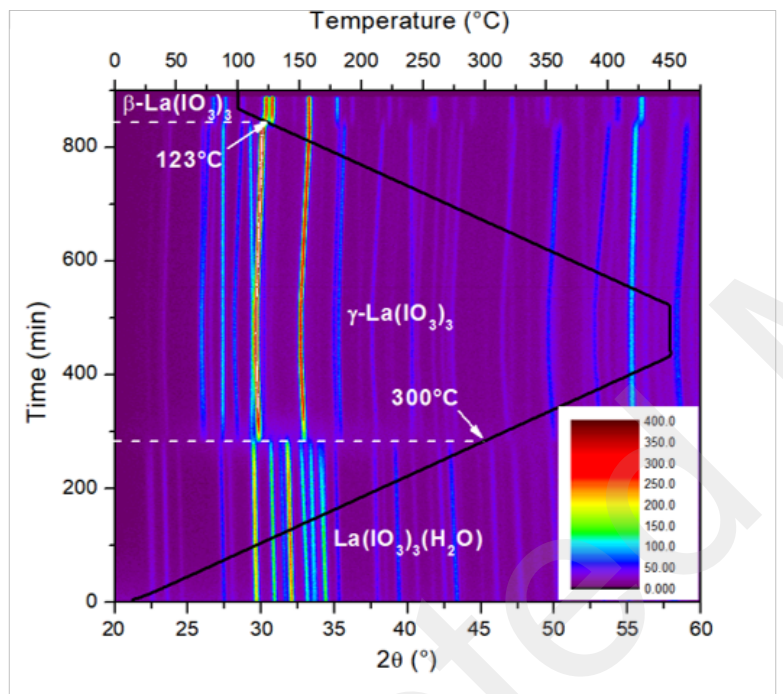

Figure 4. (a) DSC (dark curve) and TG (dotted curve, $\Delta \mathrm{m}$ ) curves versus temperature between 50 and $400^{\circ} \mathrm{C}$, showing thermic behavior of $\mathrm{La}\left(\mathrm{IO}_{3}\right)_{3}\left(\mathrm{H}_{2} \mathrm{O}\right)$ with two transitions at $313^{\circ} \mathrm{C}\left(\max\right.$ at $\left.325^{\circ} \mathrm{C}\right)$ and at $134^{\circ} \mathrm{C}\left(\max\right.$ at $\left.123^{\circ} \mathrm{C}\right)$ during heating and cooling, respectively. (b) Powder XRD patterns recorded as a function of temperature from room temperature to $450^{\circ} \mathrm{C}$. The black line shows the temperature cycle as a function of time with heating (positive slope $\left(1^{\circ} \mathrm{C}\right.$ $\left.\left.\min ^{-1}\right)\right)$, a dwell at $450^{\circ} \mathrm{C}$ and cooling (negative slope). The Bragg intensities are visible with a color bar (legend shown in bottom-right corner).

\section{Discussion on phase transformation in solution}

Under hydrothermal conditions, we observe the phase transformation from $\mathrm{La}\left(\mathrm{IO}_{3}\right)_{3}\left(\mathrm{H}_{2} \mathrm{O}\right)$ to $\mathrm{La}\left(\mathrm{IO}_{3}\right)_{2.66}(\mathrm{OH})_{0.33}$ leading to $\alpha$ - $\mathrm{La}\left(\mathrm{IO}_{3}\right)_{3}$. The transformation of a hydrate compound in hydroxylate requires three lanthanum entities with loss of two water molecules and one iodic acid:

$$
3 \mathrm{La}\left(\mathrm{IO}_{3}\right)_{3}\left(\mathrm{H}_{2} \mathrm{O}\right) \rightarrow \mathrm{La}_{3}\left(\mathrm{IO}_{3}\right)_{8}(\mathrm{OH})+2 \mathrm{H}_{2} \mathrm{O}+\mathrm{HIO}_{3}
$$

From the structural point of view both tri-nuclear entities possess a triangular shape as seen in the Figure $\mathbf{5}$ a $\boldsymbol{\&} \mathbf{b}$. On
Figure 5a, the water molecule coordinated to the lanthanum atom ( $\mathrm{La}-\mathrm{O} 1=2.575 \AA$ ) in the $\mathrm{La}\left(\mathrm{IO}_{3}\right)_{3}\left(\mathrm{H}_{2} \mathrm{O}\right)$ structure is localized at the center of an almost equilateral triangle of three La atoms. The lanthanum atoms linked by bis-monodentate bridging iodates (022-12-023 and O21-12-023) are distant of $6.190 \AA$ and $6.788 \AA$ respectively, while for the lanthanum atoms doubly bridged by two bis-monodentate bridging iodates (011-I1-012) the distance is $6.750 \AA$. These three La atoms with the water molecule in a center are already linked together and can be considered as the precursor of the $\left\{\mathrm{La}_{3}-\left(\mu_{3} \mathrm{OH}\right)\right\}$ entity of $\mathrm{La}\left(\mathrm{IO}_{3}\right)_{2.66}(\mathrm{OH})_{0.33}$. The 01 oxygen atom of the aquo ligand at $4.091 \AA$ and $5.077 \AA$ from the other two La atoms is not sterically hindered and can condense to form the $\left\{\mathrm{La}_{3}-\left(\mu_{3} \mathrm{OH}\right)\right\}$ tri-nuclear entity during heating. Thus, this condensation leads to shortening metal distances with a coordination rearrangement of iodate ligands: from bis-monodentate bridging in the hydrate compound, they become $\mu_{2}-\mathrm{O}$ bridging in hydroxylate compound. In this pre-organization, the shortest interatomic distances La $\cdots O$ are: La $\cdots 021=4.358 \AA \quad$ (in the La-O21-12-O23-La bridge) or La $\cdots 022=4.428 \AA$ (in the La-O22-12-O23-La bridge).

As shown Figures $\mathbf{5 b}$ and $\mathbf{5 9}$, in the tri-nuclear entity, the La polyhedron shares one face with the two other La atoms through the $\mu_{3}-\mathrm{O} 9 \mathrm{H}$ hydroxyl group and $\mu_{2}-\mathrm{O} 1$ and $\mu_{2}-\mathrm{O} 5$ oxygen atoms of 11 and 15 iodate ligands, respectively. This sharing face induces a constrained system with short $\mathrm{La}^{3+} \ldots \mathrm{La}^{3+}$ distances $(4.064 \AA)$, resulting in significant electrostatic repulsions.

Therefore, this system evolves towards the structure $\alpha-\mathrm{La}\left(\mathrm{IO}_{3}\right)_{3}$ in which the tri-nuclear entity becomes linear (with a La1-La2La3 angle at $144^{\circ}$ ) (Figures 5c and S10), corresponding to the following reaction:

$$
\mathrm{La}\left(\mathrm{IO}_{3}\right)_{2.66}(\mathrm{OH})_{0.33}+\mathrm{HIO}_{3} \text { (in excess) } \rightarrow \alpha-\mathrm{La}\left(\mathrm{IO}_{3}\right)_{3}
$$

In $\alpha-\mathrm{La}\left(\mathrm{IO}_{3}\right)_{3}$, La atoms share only one edge through two $\mu_{2}-\mathrm{O}$ oxygen atoms of iodate groups leading to longer La...La distances $(4.556 \AA$ and $4.588 \AA$ ). Furthermore, the density increases significantly from $4.91 \mathrm{~g} . \mathrm{cm}^{-3}$ for the hydrate, to $5.25 \mathrm{~g} . \mathrm{cm}^{-3}$ for the hydroxylate and to $5.52 \mathrm{~g} . \mathrm{cm}^{-3}$ for the $\alpha$ - $\mathrm{La}\left(\mathrm{IO}_{3}\right)_{3}$ phase. This $\alpha$-phase obtained at high temperature is the most compact and rationally the most stable (Table S1). 


\begin{tabular}{|c|c|c|c|c|}
\hline \multirow{3}{*}{ Compound } & \multicolumn{2}{|c|}{ La-O } & \multicolumn{2}{|c|}{ La $\cdots$ La } \\
\hline & Bond length (Å) & Coordination & Distance (Å) & {$[\mathrm{X}]$ Number of } \\
\hline & & number [CN] & & La atom neighbors \\
\hline $\mathrm{La}\left(\mathrm{IO}_{3}\right)_{3}\left(\mathrm{H}_{2} \mathrm{O}\right)$ & $2.473(4)-2.883(4)$ & [9] & $6.190(1)-7.177(1)$ & {$[11]$} \\
\hline $\mathrm{La}\left(\mathrm{IO}_{3}\right)_{2.66}(\mathrm{OH})_{0.33}$ & $2.441(2)-2.856(4)^{a}$ & [9] & $4.064(1)-7.064(1)$ & [8] \\
\hline$\alpha-\operatorname{La}\left(\mathrm{IO}_{3}\right)_{3}{ }^{\mathrm{b}}$ & $2.416(13)-2.834(12)$ & [9] & $4.556(7)-7.511(7)$ & [8] \\
\hline & $2.449(12)-2.775(12)$ & [9] & $4.556(7)-7.511(7)$ & [10] \\
\hline & $2.490(12)-2.786(12)$ & [10] & $4.588(7)-7.424(9)$ & [8] \\
\hline
\end{tabular}

Table 3. La-O Bond Lengths and $\mathrm{La} \cdots \mathrm{La}$ Distances in $\mathrm{La}\left(\mathrm{IO}_{3}\right)_{3}\left(\mathrm{H}_{2} \mathrm{O}\right), \mathrm{La}\left(\mathrm{IO}_{3}\right)_{2.66}(\mathrm{OH})_{0.33}$ and $\alpha-\mathrm{La}\left(\mathrm{IO}_{3}\right)_{3},{ }^{\mathrm{a}} \mathrm{Data}$ taken from ref. $26 .{ }^{\mathrm{b}} \mathrm{Data}$ taken from ref. 15.

(a)

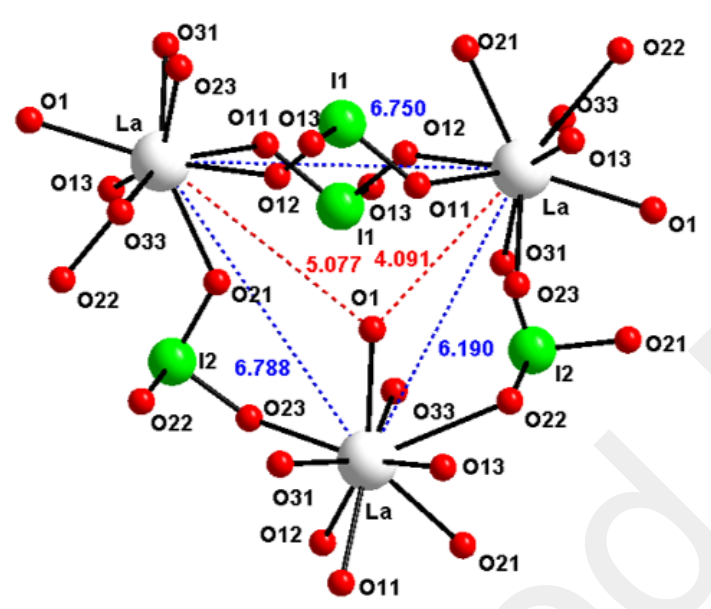

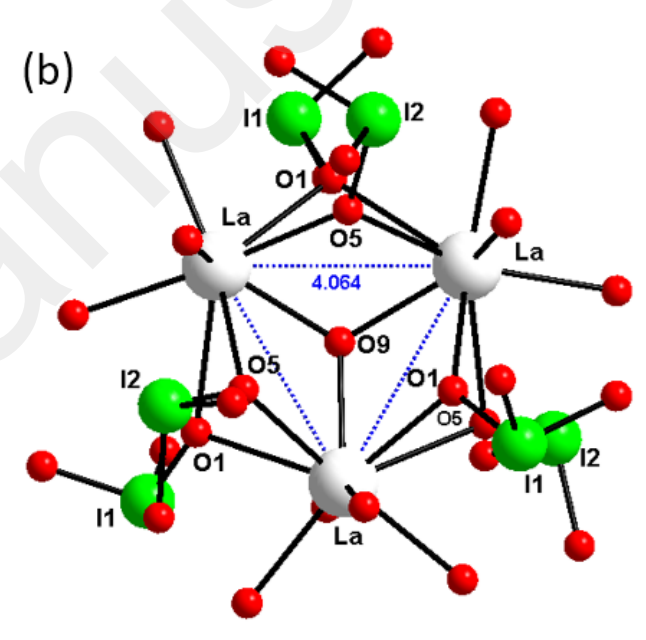

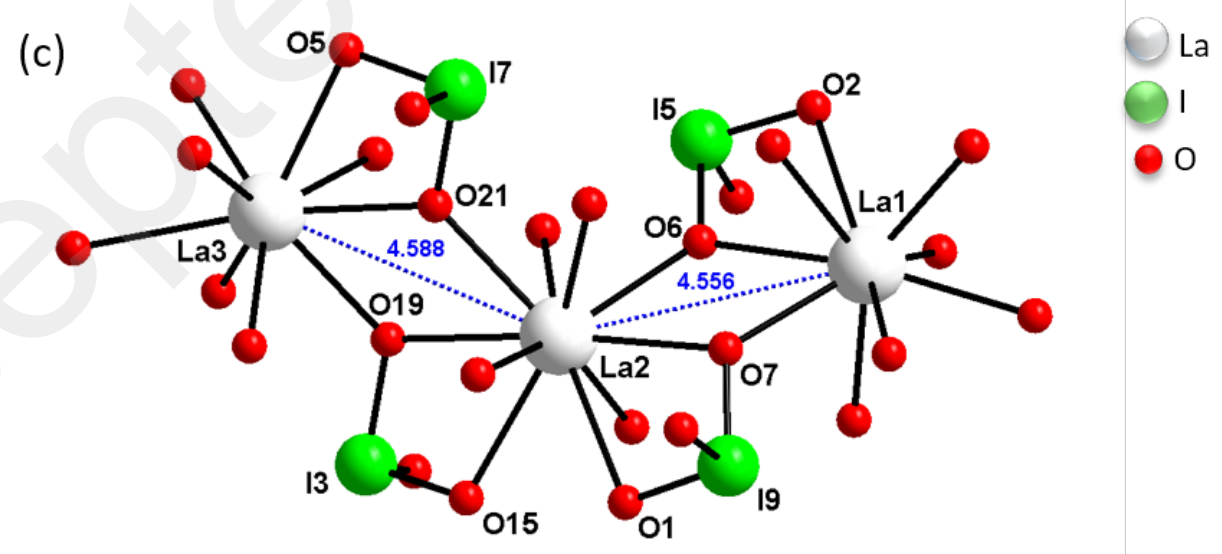

Figure 5. The different lanthanum environments in the structure (a) $\mathrm{La}\left(\mathrm{IO}_{3}\right)_{3}\left(\mathrm{H}_{2} \mathrm{O}\right)$, the water molecule $(\mathrm{O} 1)$ is situated at the center of a quasi-equilateral triangle, $(\mathrm{b})$ $\mathrm{La}\left(\mathrm{IO}_{3}\right)_{2.66}(\mathrm{OH})_{0.33}, \mu_{3}$-oxygen of the hydroxyl group lying on the 3-fold axis is noted $\mathrm{O} 9$ and (c) $\alpha$ - $\mathrm{La}\left(\mathrm{IO}_{3}\right)_{3}$, the tri-nuclear entity is linear. The La $\cdots$ La distances $($ blue dashed points) are written on the different entities, in $\AA$. Hydrogen atoms have been omitted. 


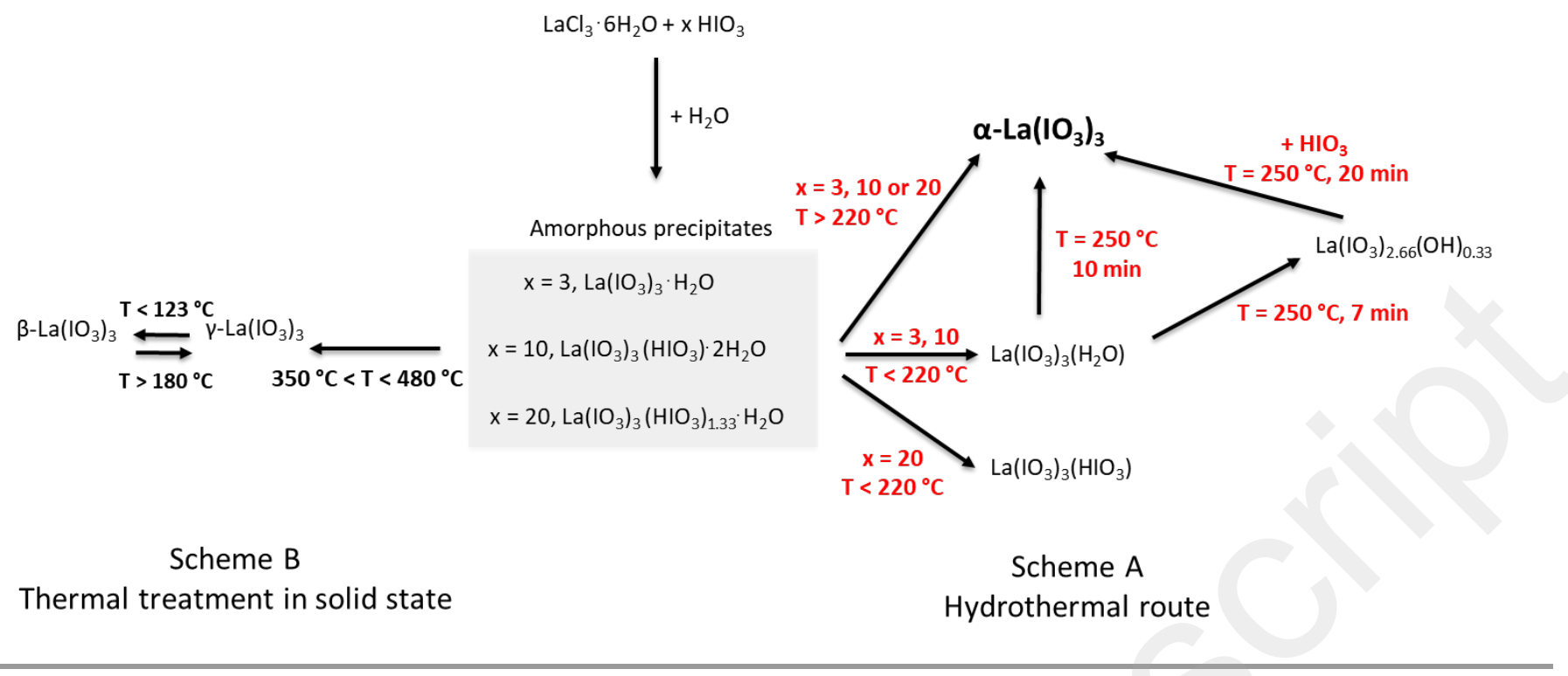

Figure 6. Scheme of the reactions and phase transformations under hydrothermal conditions and under thermal treatment in solid state.

\section{Conclusions}

The formation of lanthanum iodate compounds, starting from amorphous precipitates, was studied through a microwave-assisted hydrothermal process. The thermal behavior studies of amorphous precipitates allow us to propose chemical formulas for the various $\left[\mathrm{La}^{3+}\right]:\left[\mathrm{IO}_{3}{ }^{-}\right]$ratios. The nature of the crystallized compound depends on the initial $\left[\mathrm{La}^{3+}\right]:\left[\mathrm{IO}_{3}{ }^{-}\right]$ratio and essentially on synthesis temperature, with the non-centrosymmetric $\alpha-\mathrm{La}\left(\mathrm{IO}_{3}\right)_{3}$ phase requiring temperatures higher than $220^{\circ} \mathrm{C}$ to be formed. $\mathrm{La}\left(\mathrm{IO}_{3}\right)_{3}\left(\mathrm{H}_{2} \mathrm{O}\right)$ phase is formed at lower temperature for a $\left[\mathrm{La}^{3+}\right]:\left[\mathrm{IO}_{3}{ }^{-}\right]$ratio of $1: 3$ and $1: 10$, whereas $\mathrm{La}\left(\mathrm{IO}_{3}\right)_{3}\left(\mathrm{HIO}_{3}\right)$ is formed for a ratio of 1:20, as presented in the scheme A (Figure 6).

Phase transformations, studied in solution under hydrothermal conditions, are also reported in the scheme A. Interestingly, the new hydrate $\mathrm{La}\left(\mathrm{IO}_{3}\right)_{3}\left(\mathrm{H}_{2} \mathrm{O}\right)$ can be transformed into an optically interesting $\alpha-\mathrm{La}\left(\mathrm{IO}_{3}\right)_{3}$ phase through the formation of the reaction intermediate $\mathrm{La}\left(\mathrm{IO}_{3}\right)_{2.66}(\mathrm{OH})_{0.33}$. The evolution of these structures can be explained by rearrangements of the coordination scheme of iodate ligands on lanthanum atoms, leading to the most stable $\alpha-\mathrm{La}\left(\mathrm{IO}_{3}\right)_{3}$ phase. $\alpha-\mathrm{La}\left(\mathrm{IO}_{3}\right)_{3}$ possesses the highest density of lanthanum iodates polymorphs and furthermore no structural transition is observed before its decomposition at $510^{\circ} \mathrm{C}$. This phase is only obtained in aqueous solution under hydrothermal treatment. In solid-state reaction, phase transformations of the amorphous precipitates lead finally to $\mathrm{\gamma}$ - $\mathrm{La}\left(\mathrm{IO}_{3}\right)_{3}$ with structural transition in $\beta$ - $\mathrm{La}\left(\mathrm{IO}_{3}\right)_{3}$ by cooling at $123^{\circ} \mathrm{C}$ as shown in Figure 6.

\section{Conflicts of interest}

There are no conflicts to declare.

\section{Acknowledgements}

The authors thank the French-Swiss Interreg $\mathrm{V}$ program for financial support (Project OncoNanoscreen). Mathieu Salaün and Paul Chometon from the Institut Néel are thanked for their assistance in temperature-dependent $\mathrm{X}$-ray diffraction and thermal analysis respectively.

\section{References}

1 W. Guo, F. Liang, W. Yin, Z. Li, X. Luo, Z.S. Lin, J. Yao, A. Mar, Y. Wu, Chem. Mater. 2019, 31(8), 3034

2 V. Boutou, A. Vernay, C. Félix, F. Bassignot, M. Chauvet, D. Lupinski, B. Boulanger, Optics Letters, 2018, 43, 153770

3 C. L. Hsieh, R. Grange, Y. Pu, D. Psaltis, Biomaterials, 2010, 31, 2272

4 R. Ladj, A. Bitar, M. Eissa, Y. Mugnier, R. Le Dantec, H. Fessi, A. Elaissari, J. Mater. Chem. B, 2013, 1, 1381-1396

5 F. Liang, L. Kang, Z. Lin, Y. Wu, Y. Cryst. Growth Des., 2017, 17(4), 2254

6 M.-L. Liang, C.L. Hu, F. Konga J.-G. Mao, J. Am. Chem. Soc. 2016138 (30), 9433

7 E.O Chi, K.M. Ok, Y. Porter, P.S. Halasyamani, Chem. Mater. 2006, 18 (8), 2070-2074

8 H.Y. Chang, S.H. Kim, P.S. Halasyamani, K.M Ok J. Am. Chem. Soc. 2009, 131, 2426-2427

9 D. Phanon, I. Gautier-Luneau, Angew. Chem. Int. Ed. 2007, 46, 8488

10 D. Phanon, A. Mosset, I. Gautier-Luneau, J. Mater. Chem., 2007, 17, 1123

11 S.D. Nguyen, J. Yeon, S.H. Kim, P.S. Halasyamani, J. Am. Chem. Soc. 2011, 133(32), 12422

12 C.L. Hu, J.G. Mao, Coordination Chemistry Reviews 2015, 288, 1

13 D. Phanon, B. Bentria, D. Benbertal, A. Mosset, I. GautierLuneau, Solid State Sci. 2006, 8, 1466

14 C. Galez, Y. Mugnier, J. Bouillot. Y. Lambert, R. Le Dantec, J. Alloys Compounds, 2006, 416, 261

15 K.M. Ok, P.S. Halasyamani, Inorg. Chem. 2005, 44, 9353-9359 
16 D. Phanon, Y. Suffren, M.B. Taouti, D. Benbertal, A. Brenier, I. Gautier-Luneau J. Mater. Chem. C, 2014, 2, 2715

17 Y. Li, M. Cui, H. Yan, Y. Yu, M. Li, X. Li, L. Chu, B. Jiang, M. Qin, Materials 2018, 11, 1809

18 S. Matsumura, Mater. Res. Bull. 1971, 6(6), 469

19 Z. Hebboul, D. Benbertal, J. Mater. Environ. Science, 2018, 7(9), 565

20 B. Bentria, D. Benbertal, Z. Hebboulb, M. Bagieu-Beucher, A. Mosset, Z. Anorg. Allg. Chem. 2005, 631, 894

21 B.-P. Yang, C.-F Sun, C.-L Hu, J.-G. Mao, Dalton Trans., 2011 40, 1055

22 A. L Hector, S.J. Henderson, W. Levason, M. Webster, Anorg. Allg. Chem. 2002, 628 (1), 198-202.

23 K. Nassau, J.W. Shiever, B.E. Prescott, J. Solid State Chem. 1975, 14, 122-132

24 S. C. Abrahams, J.L. Bernstein, J. Chem. Phys. 1978, 69, 2505

25 E. E Vinogradov, G. N Tarasova Zh. Neorg. Khim. 1985, 30, 1542

26 F.F Mao, C.L. Hu, B.X. Li, J.G. Mao, Inorg. Chem. 2017, 56 14357

27 M.B Taouti, Y. Suffren, O. Leynaud, D. Benbertal, A. Brenier, I. Gautier-Luneau, Inorg. Chem. 2015, 54, 3608-3618

28 S. Regny, J. Riporto, Y. Mugnier, R. Le Dantec, S. Kodjikian, S. Pairis, I. Gautier-Luneau, G. Dantelle, Inorg. Chem. 2019, 58, 1647

29 I. Bilecka, M. Niederberger, Nanoscale, 2010, 2, 1358

30 H. Luo, B.A. Kebede, E.J. McLaurin, V. Chikan, ACS Omega, 2018, 3, 5399-5405

31 G. Yang, S.J. Park, Materials, 2019, 12, 1177

32 C.-L.Hsieh, R. Grange, Y. Pu, D. Psaltis, Opt. Express 2009, 17, 2880

33 L. Mayer, A. Slablab, G. Dantelle, V. Jacques, A.M. LepagnolBestel, S. Perruchas, P. Spinicelli, A. Thomas, D. Chauvat, M Simonneau, T. Gacoin, J.F. Roch, Nanoscale 2013, 5, 8466

34 S. Regny, K. Ledrillet, J. Riporto, I. Gautier-Luneau, Y. Mugnier, R. Le Dantec, G. Dantelle, MRS Communications 2019, 9(4), 1221

35 B.L Hayes, Microwave synthesis, Ed. CEM Publishing, 2002

36 B. Panzarella, G.A. Tompsett, K.S. Yngvesson, W.C. Conner, W.C. J. Phys. Chem. B 2007 111, 12657

37 Y. Suffren, PhD thesis (2010) Université Grenoble Alpes, France

38 A. Altomare, M. Cascarano, C. Giacovazzo, A.J. Guagliardi, J. Appl. Cryst. 1993, 26, 343

39 G. M. Sheldrick, SHELX97. Programs for crystal structure analysis (release 97-2). University of Göttingen, Germany. (1997)

40 L. J. Farrugia, J. Appl. Cryst. 1999, 32, 837

41 M. B. Taouti, A. Gacemi, D. Benbertal, I. Gautier-Luneau, Z. Kristallogr. New Cryst. Struct. 2008, 223, 179-180.

42 I. D Brown, D. Altermatt, Acta Crystallogr., Sect. B: Struct. Sci. 1985, 41, 244-247.

43 F. Zocchi, Chem. Phys. Lett. 2006, 421, 277-280.

44 F. Zocchi, J. Mol. Struct. Theochem. 2007, 805, 73-78. 